\title{
A novel early precursor cell population from rat bone marrow promotes angiogenesis in vitro
}

\author{
Andreas Brandl, Quan Yuan, Anja M Boos, Justus P Beier, Andreas Arkudas, Ulrich Kneser, Raymund E Horch \\ and Oliver Bleiziffer ${ }^{*}$
}

\begin{abstract}
Background: Some studies demonstrated therapeutic angiogenesis attributable to the effects of endothelial progenitor cells (EPC), others have reported disappointing results. This may be due to the fact that EPC populations used in these contradictory studies were selected and defined by highly variable and differing experimental protocols. Indeed, the isolation and reliable characterization of ex vivo differentiated EPC raises considerable problems due to the fact there is no biomarker currently available to specifically identify EPC exclusively. On the other hand traditional differentiation of primary immature bone marrow cells towards the endothelial lineage is a time-consuming process of up to 5 weeks. To circumvent these shortcomings, we herein describe a facile method to isolate and enrich a primary cell population from rat bone marrow, combining differential attachment methodology with cell sorting technology.

Results: The combination of these techniques enabled us to obtain a pure population of early endothelial precursor cells that show homogenous upregulation of CD31 and VEGF-R2 and that are positive for CD146. These cells exhibited typical sprouting on Matrige $\mathrm{I}^{\mathrm{T}}$. Additionally, this population displayed endothelial tube formation when resuspended in Matrige $\left.\right|^{T M}$ as well as in fibrin glue, demonstrating its functional angiogenic capacity. Moreover, these cells stained positive for Dil-ac-LDL and FITC-UEA, two markers that are commonly considered to stain differentiating EPCs. Based upon these observations in this study we describe a novel and time-saving method for obtaining a pure endothelial precursor cell population as early as $2-3$ weeks post isolation that exhibits endothelial abilities in vitro and which still might have retained its early endothelial lineage properties.
\end{abstract}

Conclusion: The rapid isolation and the high angiogenic potential of these syngeneic cells might facilitate and accelerate the pre-vascularization of transplanted tissues and organs also in a human setting in the future.

Keywords: Angiogenesis, Endothelial progenitor cells (EPC), Tissue engineering, Bone marrow, Rat

\section{Background}

The term angiogenesis defines a complex physiological process where new blood vessels are formed from preexisting vessels. In a distinctly different process of vasculogenesis, on the other hand, angioblasts differentiate into endothelial cells in situ, assembling into a vascular labyrinth. It is generally believed that EPC derive from a common hematopoietic precursor and contribute to vasculogenesis [1]. Indeed, their vasculogenic and angiogenic potential has been demonstrated in a multitude of experimental and clinical studies of tissue ischemia, thereby making them potentially useful for regenerative

\footnotetext{
* Correspondence: oliver.bleiziffer@uk-erlangen.de

Department of Plastic and Hand Surgery, Hospital of Erlangen,

Friedrich-Alexander-University of Erlangen-Nuremberg, Krankenhausstrasse 12, Erlangen 91054, Germany
}

medicine applications where generation of new blood vessels is needed. Bioengineered tissues have become an essential element in regenerative medicine and tissue engineering applications [2-4]. Once they exceed a critical size, however, their oxygenation becomes challenging and can only be maintained by a three-dimensional functional vascular network. A variety of experimental strategies have been applied to overcome this problem such as the incorporation of pro-angiogenic growth factors $[5,6]$ or endothelial progenitor cells [7] in these bioengineered constructs. Addition of EPC constitutes a relatively new approach to enhance blood vessel formation in bioartificial tissues [8]. Significant research efforts have focused on isolation, definition, selection and characterization of EPC populations. A precise definition and delineation of precursor cells with potent angiogenic properties is still a controversial subject.
C Biomed Central

(c) 2014 Brandl et al.; licensee BioMed Central Ltd. This is an Open Access article distributed under the terms of the Creative Commons Attribution License (http://creativecommons.org/licenses/by/2.0), which permits unrestricted use, distribution, and reproduction in any medium, provided the original work is properly credited. 
It has recently been recommended to avoid the term EPC altogether in favor of a precise definition of cellular phenotype [9] which again is dependent on the respective algorithm and protocol used for cell selection. Given that specific cell surface markers to identify endothelial progenitor cells are unknown, it is impossible to separate the EPC population at an early state of differentiation by using methodology based on magnetic activated cell sorting (MACS). Therefore, other approaches such as the differential attachment method [10-12] have been used to isolate EPC. However, awaiting outgrowth of a pure cell population from the pluripotent heterogenous bone marrow fraction of mononuclear cells (MNC) is very time consuming.

This study introduces the combination of differential cell attachment followed by enrichment of the cells via cell sorting as early as 2 weeks post isolation of the MNC fraction from bone marrow. Our method exploits the ability of endothelial lineage cells to take up increased amounts of acetylated low density lipoprotein (ac-LDL) via specialized scavenger receptors. As a consequence, we were able to enrich a population of putative EPC of rat bone marrow MNC with unusually high purity at an early time point. We characterized their phenotype using Flow Cytometric analyses and their angiogenic potency by tube formation assays in vitro in comparison to a rat endothelial cell line.

\section{Methods}

\section{Animals}

Male Lewis rats (Charles River Laboratories, Sulzfeld, Germany) served as donors for the bone marrow. German regulations for the care and use of laboratory animals were observed at all time. The animal care committee of the Unviversity of Erlangen and the government of Mittelfranken approved all experiments. The animals were housed in the Franz-Penzoldt-Zentrum in Erlangen and submitted to a 12-h dark/light cycle with free access to standard chow (Altromin, Hamburg, Germany) and water.

\section{Cells and culture conditions}

The rat endothelium cell line EC52 was used as a positive control for functional experiments, (A kind gift from Prof. Dr. U. Rauen, Institute of Physiological Chemistry, University of Duisburg-Essen). EC52 cells were cultured in RPMI 1640 medium, supplemented with 20\% FBS, $4 \mathrm{mM}$ L-glutamine, dexamethasone $(720 \mathrm{ng} / \mathrm{ml}$; Roche Diagnostics), penicillin $(100 \mathrm{U} / \mathrm{ml})$, and streptomycin $(100 \mathrm{mg} / \mathrm{ml})$ in a humidified atmosphere of $5 \% \mathrm{CO}_{2}$ in air (according to provider's instructions). Cells were split at $\sim 90 \%$ confluency to maintain a constant cell density.

\section{Isolation of mononuclear cells from rat bone marrow} Bones (femur and tibia of hind legs) from 6-week-old male Lewis rats were repeatedly flushed with PBS containing
$2 \%$ FBS. The washing fluid was centrifuged and the remaining pellet was resuspended in $10 \mathrm{ml}$ pre-warmed EGM MV2 medium with FBS, VEGF, $\mathrm{R}^{3}$-IGF-1, rhEGF, rhbFGF, ascorbic acid and hydrocortisone (PromoCell $\mathrm{GmbH}$, Heidelberg, Germany). This suspension was filtered into a single-cell suspension with a 70- $\mu \mathrm{m}$ Cell Strainer (BD Falcon ${ }^{\text {Ts }}$, Heidelberg, Germany). Single-cell suspension was carefully underlaid with $5 \mathrm{ml}$ of Histopaque -1077 (Sigma-Aldrich Chemie GmbH, Steinheim, Germany). The mixture was then centrifuged at 2,000 rpm for $20 \mathrm{~min}$ at $20^{\circ} \mathrm{C}$ without brake to separate the cells into three layers. The white and cloudy interphase which consists of the MNC was gently removed and washed with $10 \mathrm{ml}$ of pre-warmed medium. The pellet was resuspended in complete medium and seeded in 12 -well plates with a density of $2 \times 10^{6}$ cells/well. After $24 \mathrm{~h}$ the non-adherent cell population was transferred to gelatin-coated (1\%) plates to remove rapidly adherent hematopoietic cells. Only the cell population which was non-adherent after $24 \mathrm{~h}$ was subjected to additional evaluation.

\section{Flow cytometry (FACS) analyses}

Cells were stained for the presence of CD31 (AbD Serotec, Düsseldorf, Germany) to demonstrate the presence of endothelial cells, and CD146 (R\&D Systems GmbH, Wiesbaden-Nordenstadt, Germany), a cell adhesion molecule that is currently used as a marker for endothelial cell lineage. Additionally, cells were stained for VEGF receptor-2 (KDR, Abcam, Cambridge, UK). All stainings were carried out according to manufacturer's protocols. Expression of cell surface markers was measured with a FACS-Calibur running the Cell Quest software (BD Biosciences, San Diego, CA, USA). Raw data were analyzed with the FlowJo software (Tree Star, Inc., Ashland, OR, USA). The primary antibody was omitted in the negative controls. The given percentages in brackets represent the mean of 4 independent isolations and FACS-analyses with respect to the upregulation of indicated cell surface markers and the corresponding standard deviation respectively.

\section{ac-LDL-Uptake and cell sorting}

Cells were incubated with $2.5 \mu \mathrm{g} / \mathrm{ml}$ Alexa Fluor ${ }^{\odot}$ 488-ac-LDL or DiI-ac-LDL (Life Technologies $\mathrm{GmbH}$, Darmstadt, Germany) for $4 \mathrm{~h}$ at $37^{\circ} \mathrm{C}$ and $5 \% \mathrm{CO}_{2}$. Cells were subsequently washed twice with PBS and directly analyzed by fluorescence microscopy. Pictures were taken with an Olympus IX81 inverted microscope running the cellSens $^{\oplus}$ imaging software (Olympus, Center Valley, PA, USA). To separate and select the cells that had taken up the ac-LDL, FACS analysis and sorting was carried out using a FACS Aria II SORP (BD Biosciences, San Diego, CA, USA). This machine is part of the Core Unit Cell Sorting and Immunomonitoring Facility Erlangen. 
Positive and negative cell fractions were collected and seeded again in complete medium (EGM2 MV) for further analysis.

\section{FITC-UEA binding}

After incubation with Dil-ac-LDL, the selected cell population was washed twice with PBS and incubated with $5 \mu \mathrm{g} / \mathrm{ml}$ FITC-UEA (Sigma-Aldrich Chemie GmbH, Steinheim, Germany) at $37^{\circ} \mathrm{C}$ and $5 \% \mathrm{CO}_{2}$. After an additional washing step with PBS, cells were analyzed by fluorescence microscopy.

\section{In Vitro capillary tube formation assay using matrige $\mathrm{l}^{\mathrm{TM}}$ and fibrin}

For analysis of capillary tube formation, $75 \mu \mathrm{l}$ of $\mathrm{BD}$ Matrigel $^{\mathrm{ma}}$ (Becton Dickinson, Heidelberg, Germany), an extracellular mouse sarcoma matrix (Engelbreth-HolmSwarm tumor) which is a well-known pro-angiogenic stimulus in vitro and in vivo, was placed into the wells of a 96-well plate (Falcon, Heidelberg, Germany) and incubated at $37^{\circ} \mathrm{C}$ for 60 minutes. Cells were harvested and suspensions containing $5 \times 10^{4}$ cells in $150 \mu \mathrm{l}$ of EGM MV2 medium were seeded onto the Matrigel $^{\mathrm{Tm}}$ coated 96-well plates and incubated for $24 \mathrm{~h}$ at $37^{\circ} \mathrm{C}$ and $5 \% \mathrm{CO} 2$. The same procedure was used when cells were resuspended in Matrigel $^{\mathrm{mw}}$, only that $1 \times 10^{5}$ cells were used under these conditions. After clot formation, $200 \mu \mathrm{l}$ EGM2 MV was added on top. Additionally, cells $\left(5 \times 10^{5}\right)$ were resuspended in $500 \mu \mathrm{l}$ fibrin glue (TISSEEL Kit (Fibrin Sealant), Baxter Healthcare Corporation Westlake Village, CA 91362 USA), consisting of the two components Fibrin $(1.5 \mathrm{mg} / \mathrm{ml}, 300 \mu \mathrm{l})$ and Thrombin $(0.6 \mathrm{IU} / \mathrm{ml}$, $200 \mu \mathrm{l})$ and seeded in 48-well plates. After clot formation, $500 \mu \mathrm{l}$ EGM2 MV was added on top. Capillary tube formation was observed under an inverted Leica DMIL microscope and photos were taken using the Leica application suite software (Leica Microsystems GmbH, Wetzlar, Germany) after $24 \mathrm{~h}$ of incubation.

\section{Results}

Cell morphology and surface marker expression of isolated rat BM-cells 2 weeks post isolation

Rat MNC isolated from bone marrow by density gradient and cultured on Gelatin-coated (1\%) culture plates in EGM MV2 exhibited distinct cell morphology typical of endothelial lineage cells. These cells formed colonies that showed pronounced "cobblestone" morphology (Figure 1a). Analogous observations were made for the rat liver endothelial cell line EC52 that served as a positive control for functional experiments in this study. Furthermore, 2 weeks post-isolation, the population demonstrated to be composed of heterogenous cells in FACS-analyses. A small fraction of the cells expressed CD31 (Platelet endothelial cell adhesion molecule, PECAM-1) $(8.3 \% \pm 2.1)$
(Figure 1b). CD146, also known as the melanoma cell adhesion molecule (MCAM), was already markedly expressed on the cells with different intensity $(15.7 \pm 5.1 \%)$ (Figure 1c). Cells did not express vascular endothelial growth factor receptor 2 (VEGF-R2/KDR) at this time point (Figure 1d).

\section{Enrichment and separation of the ac-LDL-positive cell fraction by cell sorting}

A small population of the differentiated MNC derived from rat bone marrow demonstrated features of endothelial cells, i.e. they incorporated ac-LDL (Figure 2a). This fraction could be separated from the rest of the cell population using cell sorting technology. The cells were enriched and showed a purity of up to $92 \%$ (Figure $2 b$ ). Both negative and positive cell fractions were collected and reseeded on Gelatin-coated culture plates for further experiments and functional tests.

\section{In Vitro angiogenesis characteristics of sorted ac-LDL-positive and -negative cell fractions}

Positively and negatively sorted cell fractions significantly differed in terms of morphology. While the positively sorted fraction showed the "cobblestone" morphology, typical of endothelial cells and similar to the endothelial cells serving as positive control, the negatively sorted fraction exhibited an altogether different growth pattern (Figure 3, upper row). Furthermore, the capacity to form tubular networks in 2D as well as in 3D Matrigel $^{\mathrm{Tm}}$ cultures, an indicator of angiogenic potency, was significantly different when comparing positively- and negativelysorted cells. Only the positive cell fraction demonstrated network formation on Matrigel ${ }^{\text {Ts }}$ (Figure 3, $2^{\text {nd }}$ row) and organization into elongated structures that connected to each other after suspension within Matrigel ${ }^{\mathrm{m} w}$. After sorting and selection, primary cells appeared to form a higher degree of connected networks than the endothelial cells serving as positive control (Figure 3, $3^{\text {rd }}$ row). Negative control cells were unable to form any networks. Positivelysorted cells were also able to form connected tubular networks in fibrin glue (Figure 3, bottom row).

\section{Cell morphology and surface marker expression of isolated rat bone marrow-MNC}

One week after sorting and reseeding, cells were again analyzed with regard to their morphology and surface marker expression as already described above (Figure 1). Cells still grew in their typical "cobblestone" pattern and the entire population exhibited a uniform appearance with respect to their expression and expected upregulation of CD31 (20.1\% $\pm 6.85 \%)$, CD146 (93.25\% \pm $2.8 \%)$ and KDR $(26.6 \% \pm 11 \%)$ (Figuere $4 \mathrm{a}-\mathrm{d})$. Moreover, cells stained positive for DiI-ac-LDL and FITC-UEA (Figuere $4 \mathrm{e}$ and $\mathrm{f}$ ). Cells staining positive for both markers 


\section{a}

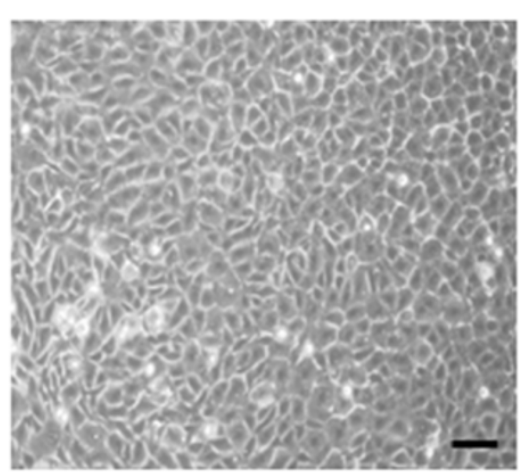

C

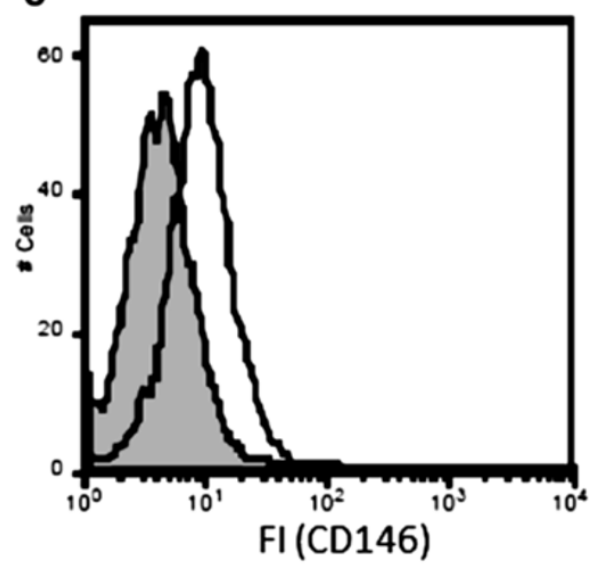

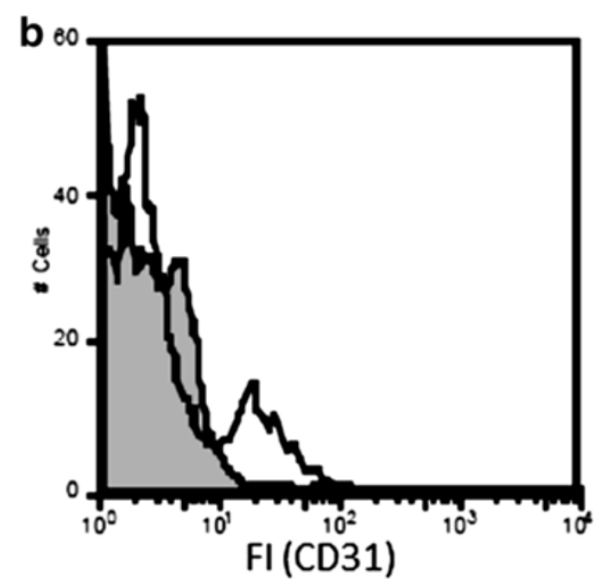

d

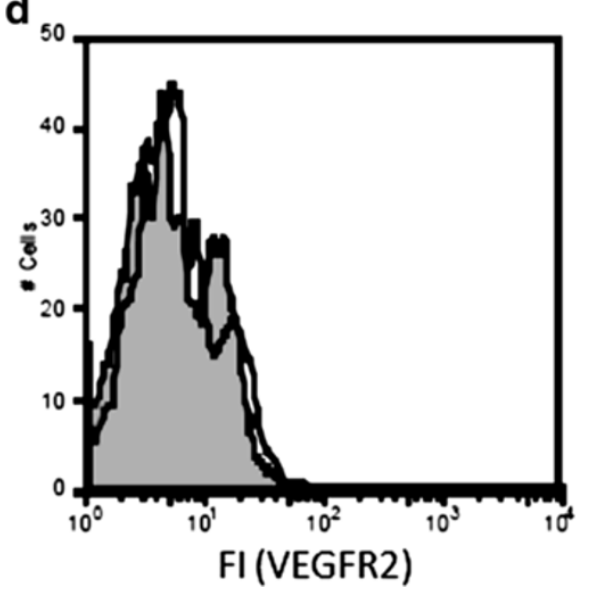

Figure 1 Flow cytometric analyses 2 weeks after isolation and cultivation of rat bone marrow MNC show heterogeneity of the cell population. (a) Cells were grown in specialized endothelial cell growth medium (EGM2 MV) for 2 weeks after isolation and their morphology was examined using light microscopy. The scale bar depicts $100 \mu \mathrm{m}$. The cells were further analyzed by Flow Cytometry for expression of endothelial cell-specific surface markers including CD31 (b), CD146 (c) and VEGF-R2 (d). Grey histograms indicate fluorescence signals of negative controls; white histograms indicate fluorescence signals of specific antigens. Results are representative of 4 separate experiments.

are commonly considered to be differentiating EPC as already reported [13].

\section{Discussion}

MNC derived from bone marrow constitute a heterogenous cell population and an easy and straight forward method to isolate and select a uniform population of cells with potent angiogenic properties, usually referred to as EPC has not been available to date. Previous studies have focused on magnetic cell sorting [14] and MNC adherent culture [15] in order to separate the EPC. Since there is no unique cell surface marker that clearly defines the properties of EPC, a population separated via magnetic sorting does not necessarily reflect progenitor cells. EPC separated by adherent culture comprise many subpopulations and obtaining a uniform cell population that expresses a homogenous set of endothelial surface markers and endothelial properties is very time consuming. In the past, early and late outgrowth EPC have been distinguished and characterized [10], but the isolation methods are fundamentally based upon their morphology, time of appearance in culture and lifespan and not upon cellular markers or properties.

Our study combines for the first time the benefits of the differential attachment method and the cell sorting technique, allowing for isolation and enrichment of a putative EPC population as early as 2 weeks post-isolation. We observed that MNC from rat bone marrow were cobblestone-shaped and appeared uniform throughout the culture 2 weeks post-isolation. Nevertheless, FACSanalyses of different endothelial cell surface markers exhibited a very heterogenous population. Hence, morphology and appearance of outgrowing cells from a miscellaneous bone marrow fraction should not be considered a uniform population. This finding precludes the application 


\section{a}
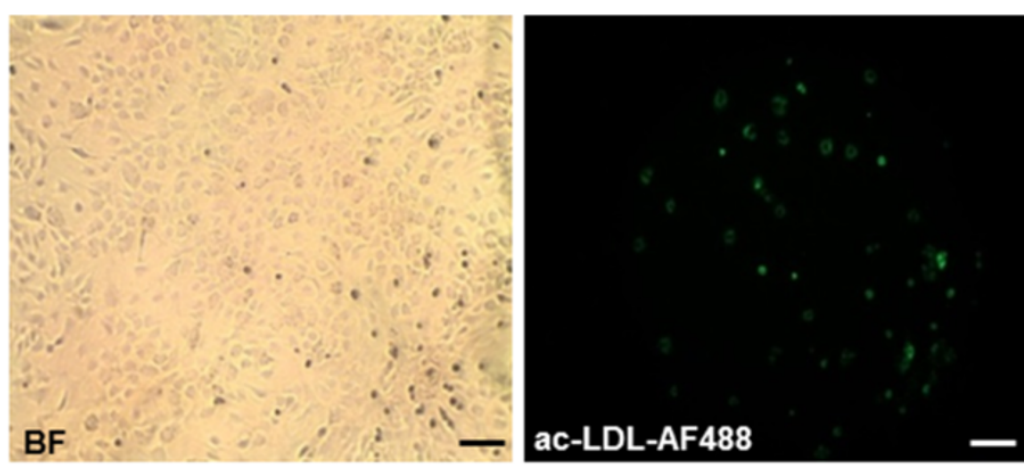

b
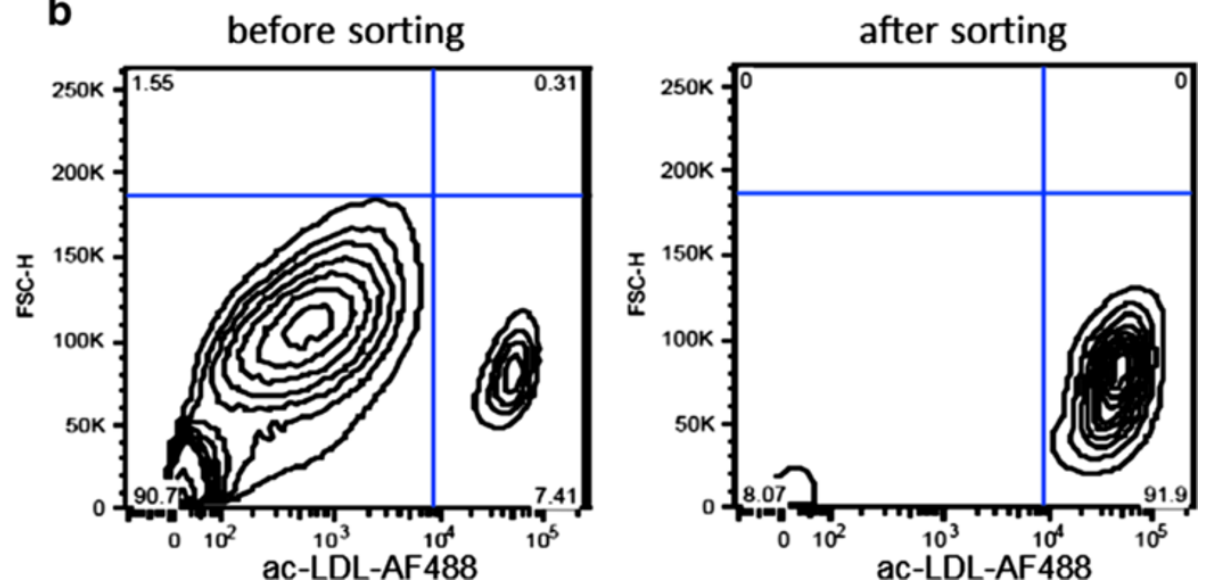

Figure 2 The heterogenous cell population can be sorted by the ability of cells of the endothelial lineage to take up ac-LDL 488 via specialized scavenger receptors. (a) Cells were incubated with $2.5 \mu \mathrm{g} / \mathrm{ml}$ ac-LDL-Alexa Fluor 488 for $4 \mathrm{~h}$ at $37^{\circ} \mathrm{C}$ and $5 \% \mathrm{CO}_{2}$. Cells were subsequently washed twice with PBS and successful uptake was visualized by fluorescence microscopy (left: brightfield, right: fluorescence). The scale bar depicts $100 \mu \mathrm{m}$. (b) By using cell sorting technology, cells that have taken up the acetylated LDL-AF488 conjugate were successfully separated from the remaining population with a purity of $92 \%$. Cell distributions are depicted in the plots.

of this early cell population in its entirety for experimental studies and therapeutic use where a precisely defined and uniform population is required.

The existing diversity of the population was emphasized when ac-LDL-uptake experiments were performed. In the past, ac-LDL has been frequently used to confirm endothelial origin of cells based on endothelial-specific increase of ac-LDL uptake [12,16,17]. We exploited the scavenger cell pathway of LDL metabolism to label the cells of the endothelial lineage within the heterogenous bone marrow population and separated the positive from the negative fraction using the cell sorting technique as early as 2 weeks post-isolation, thereby generating a cell population with a very high purity rate of $92 \%$.

The capillary tube formation assay using extracellular matrices such as Matrigel ${ }^{\mathrm{TM}}$ has been a standard in vitro assay $[8,11,18]$ to demonstrate the angiogenic potency of endothelial cells. In our study, the positively sorted cell fraction demonstrated capacity to form tubular structures and networks on and within Matrige ${ }^{\mathrm{TM}}$ just as efficiently as the control endothelial cell line EC52, while the negatively sorted cells failed to do so. This clearly emphasizes that it is highly important to separate the cells of this heterogenous early population before therapeutic use. Additionally, the positively sorted cell fraction showed network formation when the cells were suspended in fibrin glue. Fibrin is a versatile biopolymer and the prototypical extracellular matrix for tissue regeneration and wound healing applications not only in animal studies but even more so for clinical use where Matrigel ${ }^{\mathrm{TM}}$ cannot be employed given that it is of tumor origin. Fibrin, on the other hand, is biocompatible, biodegradable, easily processable and, most importantly, approved for clinical use. It has also been used in a wide variety of experimental studies towards generation of vascularized bioartificial tissues as an extracellular matrix, cell carrier and growth factor release system $[5,19,20]$.

Our positively sorted cell population showed upregulation and expression of CD31 and KDR with different intensity. These molecules are frequently used as markers to demonstrate the presence of endothelial cells $[11,12,21,22]$. All cells stained positively for CD146, a cell 


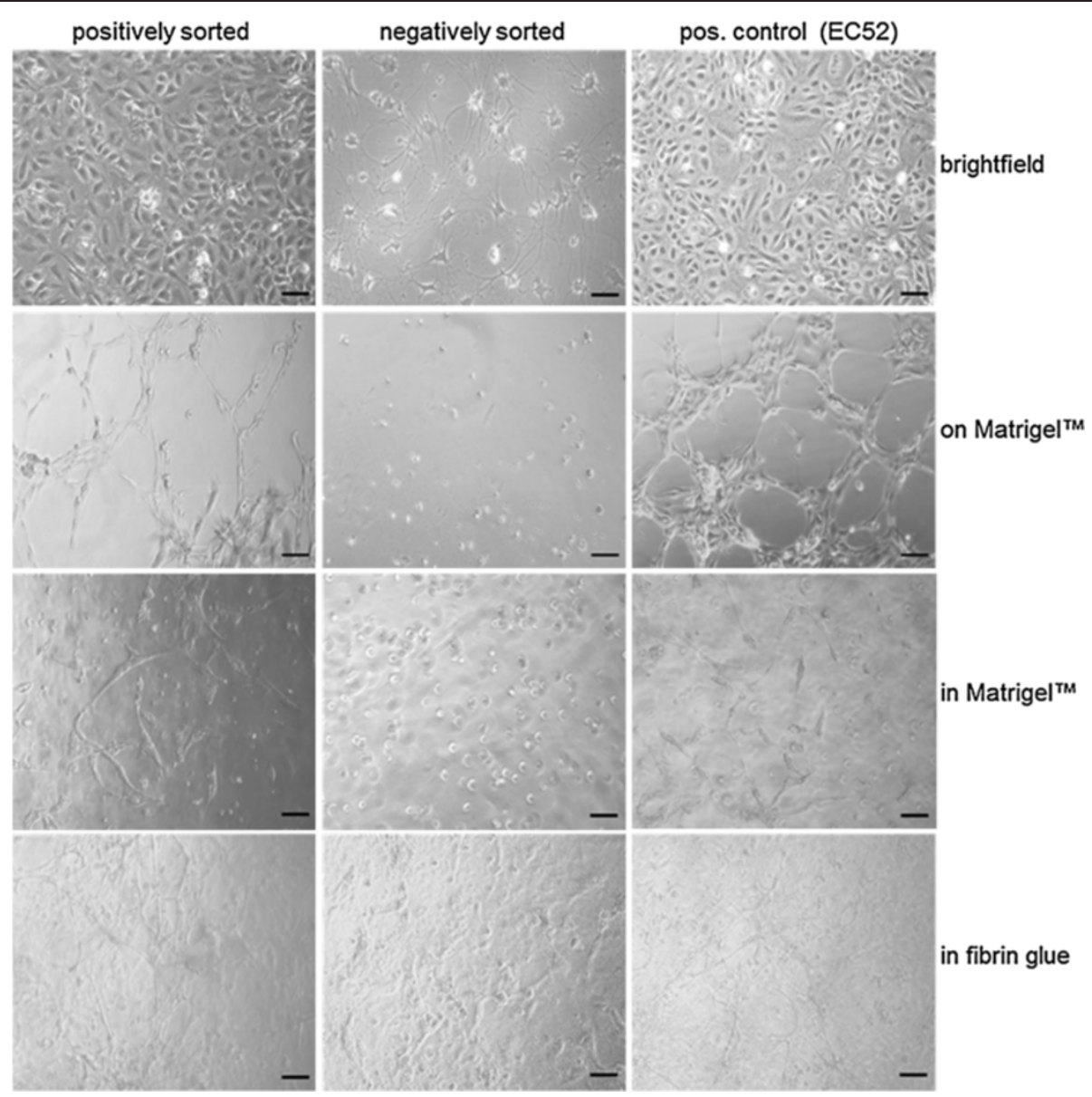

Figure 3 Angiogenic potence in Matrigel and fibrin glue of positively sorted primary cells is equal to an endothelial cell line. Positively sorted cells, negatively sorted cells and the liver endothelial cell line EC52 (pos. control) were seeded in cell culture flasks and their phenotype was investigated with light microscopy (top row). $5 \times 10^{4}$ cells of each population were seeded on Matrige ${ }^{\mathrm{TM}}\left(2^{\text {nd }}\right.$ row) or resuspended in Matrige $\mathrm{I}^{\mathrm{TM}}$ ( $3^{\text {rd }}$ row) and $1 \times 10^{5}$ cells of each population were suspended in fibrin glue (bottom row) to investigate their performance in tube formation assays. Microscope pictures were taken $24 \mathrm{~h}$ after cell seeding. The scale bar depicts $100 \mu \mathrm{m}$.

adhesion molecule which is currently used as a marker for endothelial cell lineage [11,23,24]. All markers exhibited a uniform expression throughout the entire cell population. Additionally, all the cells incorporated acLDL and bound the lectin UEA-1. As previously reported [13], cells staining positively for both markers are commonly considered to be differentiating EPC. These findings demonstrated homogeneity and uniformity of a cell population with high angiogenic potential after sorting. Taken together, our findings demonstrate that MNC from rat bone marrow show angiogenic characteristics which are commonly associated with EPC, including cobblestone-like morphology, lectin-binding, ac-LDLuptake, tube formation on and within Matrigel ${ }^{\mathrm{Tm}}$ or Fibrin and expression of endothelial cell surface markers. In accordance with others [9], we do not refer to this enriched population as EPC, but rather characterize them as early bone marrow-derived cells of endothelial lineage with high angiogenic potential in vitro. As a prospect, in vivo experiments with this newly isolated cell population have already been carried out by our group and will soon be published and discussed elsewhere. Briefly: We used a syngeneic arteriovenous loop (AV-loop) model in the rat which is a solitary in vivo system that is used for the microsurgical vascularization of bioartificial tissues. It illustrates the development of an emerging three-dimensional system of blood vessels and is hallmarked by its high standardization and evaluation properties. We isolated primary endothelial cells from rat bone marrow (this study) and tested their angiogenic potential in the AV-loop model remarkably soon after cell isolation. Our results demonstrate that this primary endothelial cell population effectively contributes to neo-vascularization not only through paracrine effects but also by their incorporation into the newly built vessel walls. The rapid isolation and the high angiogenic 


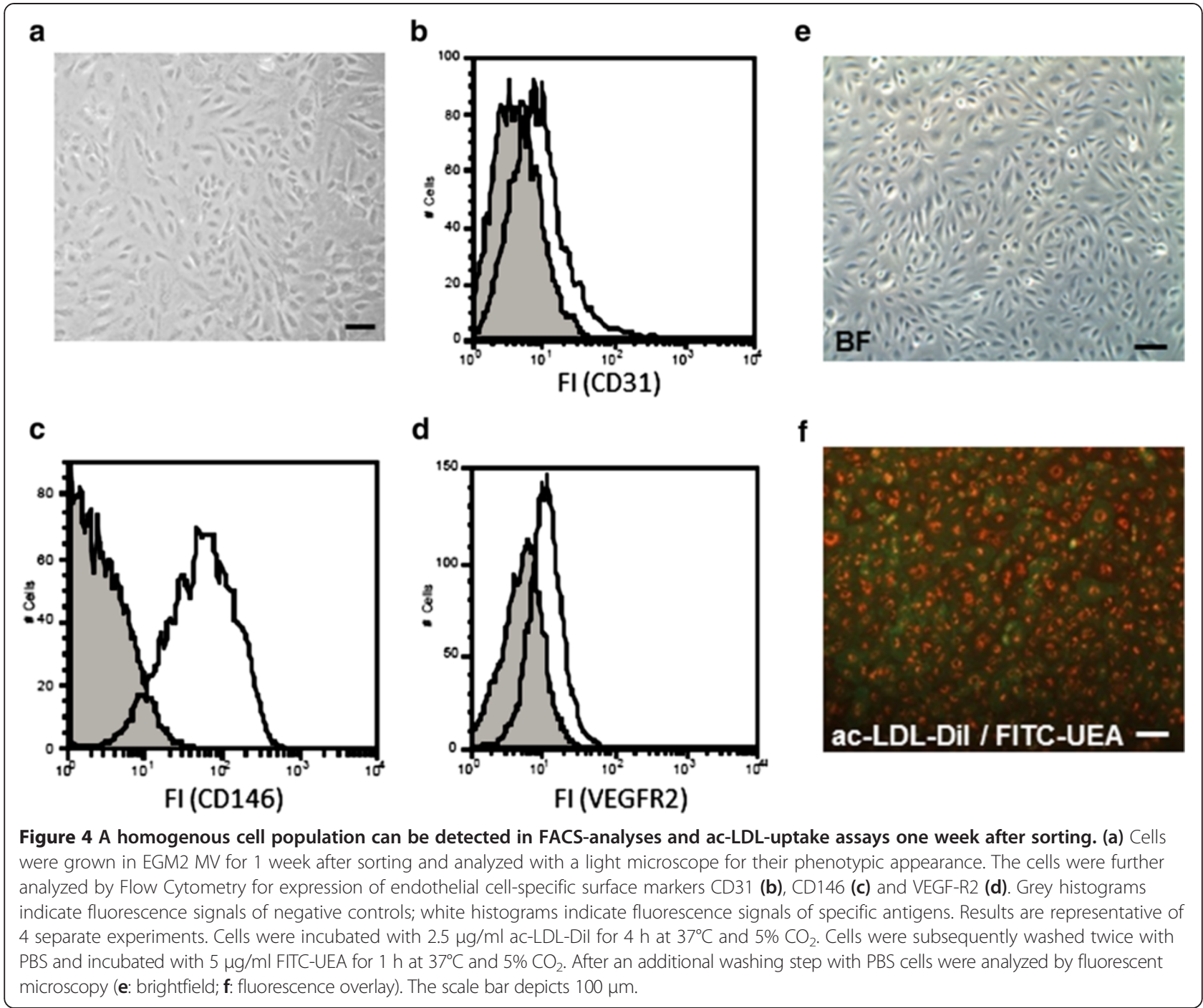

potential of these syngeneic cells might facilitate and accelerate the pre-vascularization of transplanted tissues and organs in a human setting in the future.

\section{Conclusion}

Since there is no unique cell surface marker that clearly defines the properties of EPC, it is difficult to separate this fraction at an early time point from a heterogenous cell population isolated from total bone marrow. Our method allows for generation of a defined cell population as early as 2 to 3 weeks after isolation for experimental use in angiogenesis studies in vitro and in vivo which is characterized by high purity and retains progenitor cell properties. Based upon our findings we define this population as an early bone marrow-derived endothelial cell lineage with high angiogenic potential in vitro proved by FACS analyses with regard to upregulation of specific endothelial cell surface markers, the ability of sprouting and tube formation on and in Matrigel $^{\mathrm{TM}} /$ fibrin glue as well as positive staining for DiI-ac-LDL and FITC-UEA.

\section{Abbreviations}

EPC: Endothelial progenitor cells; MACS: Magnetic activated cell sorting; MNC: Mononuclear cells; ac-LDL: acetylated low density lipoprotein; FACS: Fluorescence activated cell sorting; VEGF-R2: Vascular endothelial cell growth factor receptor 2; KDR: Kinase insert domain receptor.

\section{Competing interests}

The authors declare that there are no conflicts of interest that would prejudice the impartiality of this scientific work.

\section{Authors' contributions}

$A B, O B$ and $U K$ designed research. $A B$ and $Q$ J performed research. $A B, O B$, $\mathrm{Q}, \mathrm{AMB}, \mathrm{AA}, \mathrm{JPB}$, and $\mathrm{UK}$ analyzed data. $\mathrm{AB}$ and $\mathrm{OB}$ wrote the manuscript. All authors read and approved the final manuscript.

\section{Acknowledgments}

We would like to thank Prof. Dr. U. Rauen of the Institute of Physiological Chemistry, University of Duisburg-Essen, for kindly providing the liver endothelial cell line EC52. We also acknowledge the Core Unit-Cell 
Sorting and Immunomonitoring, Erlangen University, especially Uwe Appelt and Markus Mroz. This study was funded by grants from the Else Kröner-FreseniusStiftung (O.B.) and the Xue Hong and Hans Georg Geis-Stiftung (R.E.H).

Received: 25 April 2013 Accepted: 21 March 2014

Published: 26 March 2014

\section{References}

1. Asahara T, Murohara T, Sullivan A, Silver M, van der Zee R, Li T, Witzenbichler B, Schatteman G, Isner JM: Isolation of putative progenitor endothelial cells for angiogenesis. Science 1997, 275:964-967.

2. Horch RE, Kneser U, Polykandriotis E, Schmidt VJ, Sun J, Arkudas A: Tissue engineering and regenerative medicine -where do we stand? J Cell Mol Med 2012, 16:1157-1165.

3. Polykandriotis $E_{1}$ Schmidt VJ, Kneser U, Jianming S, Boccaccini AR, Horch RE: Bioreactors in regenerative medicine-from a technical device to a reconstructive alternative? Handchir Mikrochir Plast Chir 2012, 44:198-203.

4. Rath SN, Strobel LA, Arkudas A, Beier JP, Maier AK, Greil P, Horch RE, Kneser U: Osteoinduction and survival of osteoblasts and bone-marrow stromal cells in 3D biphasic calcium phosphate scaffolds under static and dynamic culture conditions. J Cell Mol Med 2012, 16:2350-2361.

5. Arkudas A, Tjiawi J, Bleiziffer O, Grabinger L, Polykandriotis E, Beier JP, Sturzl M, Horch RE, Kneser U: Fibrin gel-immobilized VEGF and bFGF efficiently stimulate angiogenesis in the AV loop model. Mol Med 2007, 13:480-487.

6. Zhang Y, Schedle A, Matejka M, Rausch-Fan X, Andrukhov O: The proliferation and differentiation of osteoblasts in co-culture with human umbilical vein endothelial cells: an improved analysis using fluorescence-activated cell sorting. Cell Mol Biol Lett 2010, 15:517-529.

7. Bleiziffer O, Hammon M, Naschberger E, Lipnik K, Arkudas A, Rath S, Pryymachuk G, Beier JP, Sturzl M, Horch RE, Kneser U: Endothelial progenitor cells are integrated in newly formed capillaries and alter adjacent fibrovascular tissue after subcutaneous implantation in a fibrin matrix. J Cell Mol Med 2011, 15:2452-2461.

8. Amini AR, Laurencin CT, Nukavarapu SP: Differential analysis of peripheral blood- and bone marrow-derived endothelial progenitor cells for enhanced vascularization in bone tissue engineering. J Orthop Res 2012, 30:1507-1515.

9. Deb A, Patterson C: Hard luck stories: the reality of endothelial progenitor cells continues to fall short of the promise. Circulation 2010, 121:850-852.

10. Hur J, Yoon CH, Kim HS, Choi JH, Kang HJ, Hwang KK, Oh BH, Lee MM, Park YB: Characterization of two types of endothelial progenitor cells and their different contributions to neovasculogenesis. Arterioscler Thromb Vasc Biol 2004, 24:288-293.

11. Kahler CM, Wechselberger J, Hilbe W, Gschwendtner A, Colleselli D, Niederegger H, Boneberg EM, Spizzo G, Wendel A, Gunsilius E, Patsch JR, Hamacher J, Patsch JR, Hamacher J: Peripheral infusion of rat bone marrow derived endothelial progenitor cells leads to homing in acute lung injury. Respir Res 2007, 8:50.

12. Yang N, Li D, Jiao P, Chen B, Yao S, Sang H, Yang M, Han J, Zhang Y, Qin S: The characteristics of endothelial progenitor cells derived from mononuclear cells of rat bone marrow in different culture conditions. Cytotechnology 2011, 63:217-226.

13. Ingram DA, Mead LE, Tanaka H, Meade V, Fenoglio A, Mortell K, Pollok K, Ferkowicz MJ, Gilley D, Yoder MC: Identification of a novel hierarchy of endothelial progenitor cells using human peripheral and umbilical cord blood. Blood 2004, 104:2752-2760.

14. Casamassimi A, Balestrieri ML, Fiorito C, Schiano C, Maione C, Rossiello R, Grimaldi V, Del Giudice V, Balestrieri C, Farzati B, Sica V, Napoli C, Sica V, Napoli C: Comparison between total endothelial progenitor cell isolation versus enriched Cd133+ culture. J Biochem 2007, 141:503-511.

15. Hill JM, Zalos G, Halcox JP, Schenke WH, Waclawiw MA, Quyyumi AA, Finkel T: Circulating endothelial progenitor cells, vascular function, and cardiovascular risk. N Engl J Med 2003, 348:593-600.

16. Fedorovich NE, Haverslag RT, Dhert WJ, Alblas J: The role of endothelial progenitor cells in prevascularized bone tissue engineering: development of heterogeneous constructs. Tissue Eng Part A 2010, 16:2355-2367

17. Voyta JC, Via DP, Butterfield CE, Zetter BR: Identification and isolation of endothelial cells based on their increased uptake of acetylated-low density lipoprotein. J Cell Biol 1984, 99:2034-2040.
18. Arnaoutova I, George J, Kleinman HK, Benton G: The endothelial cell tube formation assay on basement membrane turns 20: state of the science and the art. Angiogenesis 2009, 12:267-274.

19. Ahmed TA, Dare EV, Hincke M: Fibrin: a versatile scaffold for tissue engineering applications. Tissue Eng Part B Rev 2008, 14:199-215.

20. Polykandriotis E, Tjiawi J, Euler S, Arkudas A, Hess A, Brune K, Greil P, Lametschwandtner A, Horch RE, Kneser U: The venous graft as an effector of early angiogenesis in a fibrin matrix. Microvasc Res 2008, 75:25-33.

21. Mutunga M, Fulton B, Bullock R, Batchelor A, Gascoigne A, Gillespie Il, Baudouin SV: Circulating endothelial cells in patients with septic shock. Am J Respir Crit Care Med 2001, 163:195-200.

22. Woywodt A, Schroeder M, Mengel M, Schwarz A, Gwinner W, Haller H, Haubitz M: Circulating endothelial cells are a novel marker of cyclosporine-induced endothelial damage. Hypertension 2003, 41:720-723.

23. Smadja DM, Mauge L, Gaussem P, d'Audigier C, Israel-Biet D, Celermajer DS, Bonnet $D$, Levy $M$ : Treprostinil increases the number and angiogenic potential of endothelial progenitor cells in children with pulmonary hypertension. Angiogenesis 2011, 14:17-27.

24. Solovey A, Lin Y, Browne P, Choong S, Wayner E, Hebbel RP: Circulating activated endothelial cells in sickle cell anemia. N Engl J Med 1997, 337:1584-1590.

doi:10.1186/1471-2121-15-12

Cite this article as: Brandl et al:: A novel early precursor cell population from rat bone marrow promotes angiogenesis in vitro. BMC Cell Biology 2014 15:12.

\section{Submit your next manuscript to BioMed Central and take full advantage of:}

- Convenient online submission

- Thorough peer review

- No space constraints or color figure charges

- Immediate publication on acceptance

- Inclusion in PubMed, CAS, Scopus and Google Scholar

- Research which is freely available for redistribution 